\title{
Antecedents of Affective Commitment of Human Resource Management Practitioners Attending a Professional Body Convention
}

\author{
Molefe Jonathan Maleka, Mphoreng Magdeline Mmako, Ilze Swarts \\ Tshwane University of Technology, South Africa \\ MalekaM@tut.ac.za, MmakoMM@tut.ac.za, SwartsI@tut.ac.za
}

\begin{abstract}
In this paper, affective events theory (AET) is used to develop a model that can be used by organizations to enhance propitious work conditions that will encourage human resource management (HRM) practitioners to be affectively committed to their organizations. AET states that there are certain antecedents (i.e. distributive justice, job-related well-being, and employee engagement) that positively correlate with job satisfaction. According to AET, positive emotions have a positive indirect correlation between antecedents and job satisfaction. AET states that job satisfaction positively relates to affective commitment. The research design was cross-sectional and correlational, and the sample size was $(n=205)$.From the 300 questionnaires distributed to HRM practitioners, the response rate was $68.33 \%$. The main finding is that respondents rated the positive emotions items below the mean, and there was a significant positive relationship between distributive justice and job satisfaction $(\beta=0.61 ; p \leq 0.001)$. The data showed that job satisfaction positively correlated with affective commitment $(\beta=0.70 ; p \leq$ 0.001).Positive emotions only mediated the relationship between distributive justice and job satisfaction $(\beta=$ 0.36; $\mathrm{p} \leq$ 0.001). The study results have implications for managers' efforts to keep HRM practitioners affectively committed, as the latter were not satisfied with their remuneration. The data created awareness that when a remuneration policy is drafted, it should take cognisance that HRM practitioners who have positive emotions will be affectively committed and stay longer in organizations.
\end{abstract}

Keywords: Affective events theory, antecedents, affective commitment, human resource management practitioners, professional body

\section{Introduction}

Unlike other employees, HRM practitioners are faced with the challenge of performing a dual role (Pereira \& Fontinha, 2016). Given the dualistic nature of their role, HRM practitioners tend to focus on the commitment of other employees while neglecting their own. HRM practitioners face an ongoing challenge of improving the organization's productivity and striving to find ways of encouraging employees to be more committed and to enhance levels of engagement in their organizations (Agarwala, 2003; Chew \& Chan, 2008; Tladinyane \& Van der Merwe, 2016). According to Fareed, Isa and Noor (2016), the current labor market requires highly capable and committed HRM practitioners to sustain long-term competitive advantage. The commitment of HRM practitioners becomes critical for realizing organizational success (Gubbins \& Garavan, 2016). It is thus of paramount importance for organizations to have practices that foster commitment amongst HRM practitioners. Research shows that employees who are committed, are motivated (Mohapatra \& Sharma, 2008; Nohria, Groysberg \& Lee, 2008; Sharma, Mohapatra \& Rai, 2013), productive (Giffords, 2009), and stay in organizations (Abbott, White \& Charles, 2005; Giffords, 2009; Liou, 1995; Stallworth, 2003) (also see Meyer \& Allen, 1997, for a review of benefits). Organizational commitment is defined as a psychological attachment felt by the employees of an organization (Andolsek \& Stebe, 2004; Meyer \& Herscovitch, 2001; O'Reilly \& Chatman, 1986; Mohapatra \& Sharma, 2008). Allen and Meyer (1990) proposed a three-component conceptualisation of organizational commitment; however, for the purpose of this paper, the focus is on affective commitment, which means "employees wish to remain with the organization because of emotional attachment". Research studies during the last two decades have concentrated mostly on affective commitment (Sharma, Mohapatra \& Rai, 2013).

Prior to this study, no similar study has been conducted in the South African context and this is the gap this study aims to address. In this paper, the primary objective was to develop a model for testing the relationship between constructs that have been identified in the literature as antecedents of affective commitment. The secondary objectives are as follows:

- To explore if there is a relationship between distributive justice, job-related well-being, employee engagement, and job satisfaction. 
- To explore if positive emotions mediate the relationship between distributive justice, job-related well-being, employee engagement, and job satisfaction.

- To explore if job satisfaction positively correlates with affective commitment.

Theoretical model: Discussed in this section are the theoretical framework and research hypotheses. The section concludes with a proposed theoretical model.

\section{Theoretical framework}

In order to develop a model for testing the affective commitment of HRM practitioners, affective events theory (AET) was used as a theoretical framework for this study. This theory was developed by Weiss and Cropanzo (1996). Wegge, Van Dick, Fisher, West and Dawnson (2006) found that certain antecedents (i.e. autonomy, supervisory support, etc.) positively correlated with job satisfaction, and job satisfaction positively correlated with affective commitment. Wegge et al. (2006) study also revealed that positive emotions have a positive indirect link between antecedents and job satisfaction. Expanding on the work of Wegge et al. in this present study, we explored the relationship between antecedents (i.e. distributive justice, job-related wellbeing, and employee engagement) and the relationship between job satisfaction and affective commitment, and whether positive emotions mediated the relationship between antecedents and job satisfaction.

Relationship between distributive justice and job satisfaction: Distributive justice has its roots in Adam Smith's (1965) equity theory and is defined as "the fairness of outcomes for employees' fair distribution of resources" (in Keramati, Eslamieh and Mozaiini, 2015:962) and the benefits and workload in the organization (Ali \& Saifullah, 2014). On the other hand, job satisfaction is defined as the feeling an employee has about his/her job and/or reality (Locke, 1976). Numerous researchers have discovered a positive relationship between distributive justice and job satisfaction (Ali \& Saifullah, 2014; Altahayneh, Khasawneh \& Abedalhafiz, 2014; Fatt, Khin \& Heng, 2010; Hao, Hao \& Wang, 2016; Heidari \& Saeedi, 2012; Rahman, Haque, Elahi \& Miah, 2015; Saadati, Saadati, Asghari, Bidgoli, Ghodsi \& Bidgoli, 2016). Based on this reason, it is hypothesized as follows:

Hypothesis (H) 1: A positive relationship exists between distributive justice and job satisfaction.

Relationship between job-related well-being and job satisfaction: Another AET construct that emerged from Adams Smith's theory is job-related well-being, which has many definitions (see Diener, Sandvik \& Pavot, 1991; Rothausen, 2013). For the purpose of this study, job-related well-being comprises the feelings that make employees ecstatic, excited, inspired and energetic (Kirsten, Van der Walt \& Viljoen, 2009). Being energetic is also a dimension of employee engagement (see discussion in the next paragraph).Well-being also refers to how workers are fulfilled, joyous, and happy (Bakker \& Oerlemans, 2011).As satisfaction increases, so does job-related well-being (Faragher, Cass \& Cooper, 2005; Tufail et al., 2016). Happier employees tend to develop social resources from other employees, making them more effective in their roles (Bakker \& Oerlemans, 2011).The following hypothesis was therefore developed to test the relationship between jobrelated well-being and job satisfaction in this study:

H2: A positive relationship exists between job-related well-being and job satisfaction.

Relationship between employee engagement and job satisfaction: Employee engagement is how an employee is energized (Shuck \& Reio, 2013), absorbed, dedicated, enthusiastic, and shows vigor towards his/her job (Macey \& Schneider, 2008).Engaged employees are deeply involved, interested in their work, and they have high levels of job satisfaction (Biswas \& Bhatnagar, 2013), where as disengaged employees are disconnected from work rationally, emotionally, and motivationally (Sunny \& Joshua, 2014). Studies have shown a positive relationship between employee engagement and job satisfaction (Hanaysha, 2016; Imam \& Shafique,2014; Kamalanabhan, Prakash Sai \& Mayuri, 2009).The present study hypothesizes the following: H3: A positive relationship exists between employee engagement and job satisfaction.

Positive emotions mediating the relationship between distributive justice, job-related well-being, employee engagement, and job satisfaction: Robbins and Judge (2015) explained positive emotions as happiness, pleasure, pride, and enthusiasm. Positive emotions generate well-being (Hochwarter \& Thomson, 2010), as well as behaviour like job satisfaction (Akram, Khan, Yixin, Bhatti, Bilal, Hashim \& Akram, 2016), 
higher employee satisfaction (Ouweneel, Le Blanc \& Schaufeli, 2011; Schiopu, 2015), and higher levels of engagement (Lyubomirsky, King \& Diener, 2005). Positive emotions enhance well-being and personal success. This, in turn, benefits organizations because employees appreciate their organization's efforts to improve their well-being, which results in greater commitment (Cabrera, 2017).It can be surmised that an increase in positive emotions lead to an increase in job satisfaction, employee engagement, distributive justice, and job-related well-being. Hence the following hypothesis is advanced:

H4: Positive emotions mediate the relationship between distributive justice, job-related well-being, employee engagement, and job satisfaction

Positive relationship between job satisfaction and affective commitment: Affective commitment is defined as employees' attachment to the organization (Azeem, 2010; Eslami \& Gharakhari, 2012; Kumar \& Eng, 2011). Employees who are attached to the organization tend to be fulfilled in their work (Kanchana \& Panchanatham, 2015). Rhoades, Eisenberger and Armeli (2001) mentioned that employees are attached to organizations when there is a synchronization between their values and organizations' value systems(Bilgin \& Demirer, 2012; Fu, Bolander \& Jones, 2009; Karim, 2008; Kaplan, Ogut, Kaplan \& Aksay, 2012; Lumley, Coetzee, Tladinyane \& Ferreira, 2011; Tat, Pei-Nid \& Rasli, 2012; Yucel, 2012). It is believed that satisfied employees will be committed to their jobs and remains in the organization, while dissatisfied employees will intend to quit (Amos, Acquah, Antwi \& Azifome, 2015). These arguments lead tithe following hypothesis: H5: A positive relationship exists between job satisfaction and affective commitment.

Based on the discussion in the theoretical section, the following theoretical model is proposed:

\section{Figure 1: Proposed theoretical model for antecedents of affective commitment}

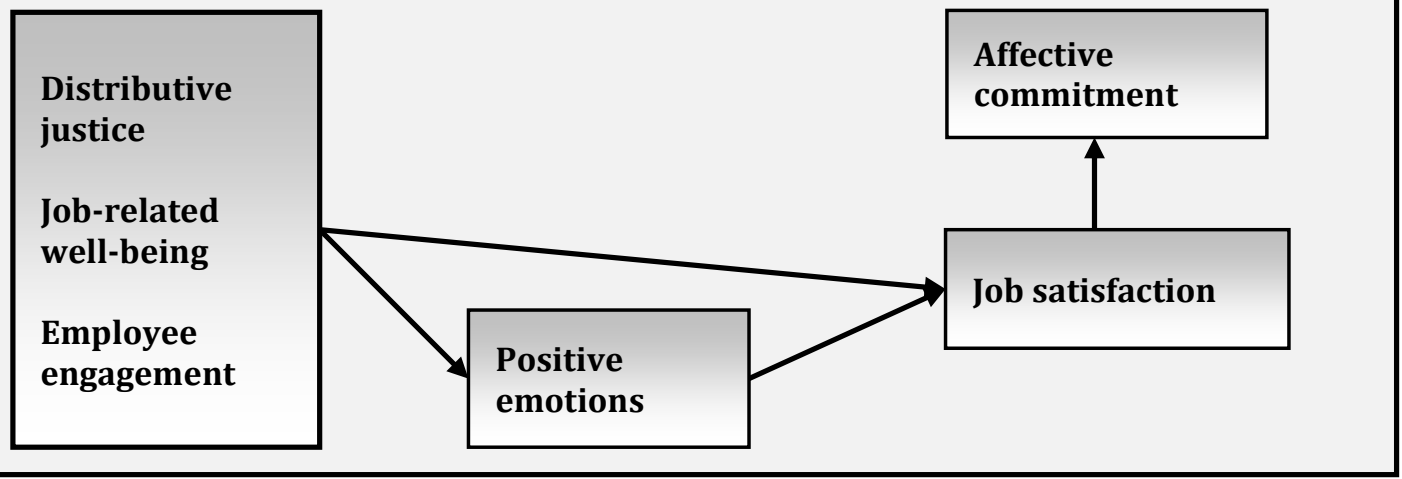

Source: Adapted from Wegge et al. (2006)

The authors of the present study included job-related well-being and employee engagement and did not include autonomy, supervisory support, and workload as antecedents of job satisfaction, Maleka, Skosana and Lekgothoane's (2016) study.

\section{Methodology}

In order to address the study's hypotheses, the research design is a survey, pre-experimental and correlational in nature. The latter assisted the researchers to test the relationship between the variables (Christensen, Johnson \& Turner, 2015). Three hundred ( $\mathrm{N}=300)$ questionnaires were distributed to HRM practitioners who attended the IPM convention in November 2016 at Emperors Palace in Kempton Park. The final sample consisted of $(n=205)$ respondents, suggesting a response rate of $68.33 \%$. The questionnaire comprised two sections, namely Section A: Biographical information (see Table 1) and Section B, which comprised validated scales. The job satisfaction scale was taken from Spector (1985), and for affective organizational commitment, four items were taken from Meyer and Allen (1997). For positive emotions, four items were taken from Watson, Clark and Tellegen (1998); four distributive justice items were taken from Price and Mueller (1986); and four items were taken from the employee engagement scale developed by Schaufeli and Bakker (2003). The scales had a seven-point Likert scale, where $1=$ strongly disagree and $7=$ strongly agree. The questionnaires stated the research purpose on the front page. Respondents were also 
informed on the front page that they must not include their names, that their participation is voluntary, and that they may withdraw from participating for any reason. This assisted in anonymising the respondents' identity. Prior to analysis, the data were coded in Microsoft Excel and exported into STATA version 13 for statistical analysis.

\section{Data analysis}

Discussed in this section are descriptive statistics (i.e. frequencies, means, and standard deviations) and inferential statistics (i.e. confirmatory factor analysis and structural equation modelling).

Sample characteristics: Presented in Table 1are sample characteristics, with the majority $(n=204)$ of respondents earning R10 000 and more a month, implying that they were middle and income workers.

Table 1: Sample demographic

\begin{tabular}{|c|c|}
\hline Variable & Frequency \\
\hline \multirow[t]{2}{*}{ Gender } & Male $(n=86)$ \\
\hline & Female $(n=112)$ \\
\hline \multirow{2}{*}{ Employment status } & Employed full-time ( $\mathrm{n}=191)$ \\
\hline & Employed part-time $(n=6)$ \\
\hline \multirow{4}{*}{ Educational level } & Certificate $(n=7)$ \\
\hline & Diploma $(n=36)$ \\
\hline & Degree $(n=80)$ \\
\hline & Postgraduate $(n=74)$ \\
\hline \multirow[t]{5}{*}{ Age } & $18-24(n=2)$ \\
\hline & $25-34(\mathrm{n}=39)$ \\
\hline & $35-44(n=71)$ \\
\hline & $45-54(n=59)$ \\
\hline & $55-65(n=27)$ \\
\hline \multirow[t]{5}{*}{ Household monthly income before tax } & Less than R10 $000 \quad(n=3)$ \\
\hline & R10 000 to R19 $999(n=10)$ \\
\hline & R20 000 to R29 $999(n=29)$ \\
\hline & R30 000 to R39 $999(n=32)$ \\
\hline & R40 000 and above $(n=122)$ \\
\hline \multirow[t]{2}{*}{ Trade union membership } & Yes $(n=71)$ \\
\hline & No $(n=128)$ \\
\hline \multirow[t]{6}{*}{ People in the household } & $1(\mathrm{n}=11)$ \\
\hline & $2(n=26)$ \\
\hline & $3(n=43)$ \\
\hline & $4(n=55)$ \\
\hline & $5(n=40)$ \\
\hline & 6 or more $(n=24)$ \\
\hline
\end{tabular}

Table 2 presents the mean scores and constructs. All the mean scores of job satisfaction were above 4 , suggesting that the respondents were moderately satisfied. In terms of affective commitment, the mean scores were above 4, with the exception of the item "I would be very happy to spend the rest of my career with the organization", which had a mean score of 3.82. This can be interpreted as that the respondents moderately disagreed that they intended to spend the rest of their career in their current workplaces. Also, the mean scores of distributive justice were above 4, which can be interpreted as that the respondents perceived their rewards as being fair. Interestingly, the mean scores of positive emotions were below 4 . This suggested that the respondents moderately disagreed that they were inspired by, enthusiastic about, and proud of their remuneration. The mean scores of employee well-being were above 4, suggesting that the respondents felt energetic, inspired, and excited at their workplaces. Lastly, all the mean scores of employee engagement were above 4 , suggesting that the respondents were moderately engaged at their workplaces. 
Table 2: Means, standard loadings, Cronbach's alphas, Dillon-Goldstein's (DG) rho, and average variance extracted (AVE)

\begin{tabular}{|c|c|c|c|c|c|}
\hline Construct and scale item & Mean & $\begin{array}{l}\text { Standardised } \\
\text { loadings }\end{array}$ & $\begin{array}{l}\text { Cronbach's } \\
\text { alphas }\end{array}$ & DG rho & AVE \\
\hline \multicolumn{6}{|l|}{ Job satisfaction } \\
\hline $\begin{array}{l}\text { I feel I am being paid a fair } \\
\text { amount for the work I do } \\
\text { (B1) }\end{array}$ & 4.179 & 0.83 & 0.84 & 0.90 & 0.75 \\
\hline $\begin{array}{l}\text { I receive a bonus once in } \\
\text { year (B2) }\end{array}$ & 5.77 & 0.27 & & & \\
\hline $\begin{array}{l}\text { I am appreciated by the } \\
\text { organization when I think } \\
\text { about the way they pay me } \\
\text { (B3) }\end{array}$ & 4.27 & 0.84 & & & \\
\hline $\begin{array}{l}\text { I feel satisfied with my } \\
\text { chances for salary increases } \\
\text { (B4) }\end{array}$ & 4.38 & 0.74 & & & \\
\hline \multicolumn{6}{|l|}{ Affective commitment } \\
\hline $\begin{array}{l}\text { I would be very happy to } \\
\text { spend the rest of my career } \\
\text { with the organization (B5) }\end{array}$ & 3.82 & 0.77 & 0.8 & 0.91 & 0.72 \\
\hline $\begin{array}{l}\text { I really feel as if this } \\
\text { organization's problems are } \\
\text { my own (B6) }\end{array}$ & 4.47 & 0.67 & & & \\
\hline $\begin{array}{l}\text { I feel a strong sense of } \\
\text { belonging to } \\
\text { organization (B7) }\end{array}$ & 4.51 & 0.90 & & & \\
\hline $\begin{array}{l}\text { I feel emotionally attached } \\
\text { to this organization (B8) }\end{array}$ & 4.38 & 0.79 & & & \\
\hline \multicolumn{6}{|l|}{ Distributive justice } \\
\hline $\begin{array}{l}\text { Overall, the rewards I } \\
\text { receive here are quite fair } \\
\text { (B9) }\end{array}$ & 4.29 & 0.80 & 0.94 & 0.96 & 0.85 \\
\hline $\begin{array}{l}\text { I am rewarded fairly for the } \\
\text { amount of effort I put in } \\
\text { (B10) }\end{array}$ & 4.03 & 0.99 & & & \\
\hline $\begin{array}{l}\text { I am rewarded fairly for the } \\
\text { work I have done (B11) }\end{array}$ & 4.01 & 0.97 & & & \\
\hline $\begin{array}{l}\text { I think my current pay level } \\
\text { is fair (B12) }\end{array}$ & 4.11 & 0.85 & & & \\
\hline \multicolumn{6}{|l|}{ Positive emotions } \\
\hline $\begin{array}{l}\text { I generally } \text { feel excited } \\
\text { about my remuneration } \\
\text { (B13) }\end{array}$ & 3.87 & 0.99 & 0.97 & 0.99 & 0.97 \\
\hline $\begin{array}{l}\text { I generally feel enthusiastic } \\
\text { about my remuneration } \\
\text { (B14) }\end{array}$ & 3.84 & 0.99 & & & \\
\hline $\begin{array}{l}\text { I generally } \\
\text { about my reel inspired } \\
\text { (B15) }\end{array}$ & 3.77 & 0.96 & & & \\
\hline $\begin{array}{l}\text { I generally feel proud about } \\
\text { my remuneration (B16) }\end{array}$ & 3.79 & 0.96 & & & \\
\hline \multicolumn{6}{|l|}{ Job-related well-being } \\
\hline My job makes me feel & 4.55 & 0.92 & 0.97 & 0.98 & 0.92 \\
\hline
\end{tabular}




\begin{tabular}{|c|c|c|c|c|c|}
\hline ecstatic (B17) & & & & & \\
\hline $\begin{array}{l}\text { My job makes me feel } \\
\text { excited (B18) }\end{array}$ & 4.76 & 0.95 & & & \\
\hline $\begin{array}{l}\text { My job makes me feel } \\
\text { energetic (B19) }\end{array}$ & 4.71 & 0.98 & & & \\
\hline $\begin{array}{l}\text { My job makes me feel } \\
\text { inspired (B20) }\end{array}$ & 4.80 & 0.92 & & & \\
\hline Employee engagement & & & & & \\
\hline $\begin{array}{l}\text { When I am working, I forget } \\
\text { everything around me (B21) }\end{array}$ & 4.57 & 0.72 & 0.83 & 0.89 & 0.67 \\
\hline $\begin{array}{l}\text { I feel happy when I am } \\
\text { working intensively (B22) }\end{array}$ & 5.00 & 0.74 & & & \\
\hline $\begin{array}{l}\text { To me, my job is challenging } \\
\text { (B23) }\end{array}$ & 4.93 & 0.78 & & & \\
\hline $\begin{array}{l}\text { It is difficult to detach } \\
\text { myself from the job (B24) }\end{array}$ & 4.60 & 0.73 & & & \\
\hline
\end{tabular}

Reliability and validity assessment: As can be observed from Table 2, the Cronbach's alphas for each of the constructs were above 0.7, suggesting that the questionnaire was reliable (Field, 2013). The DG rho was greater than 0.7, suggesting uni-dimensionality (Ravand \& Baghaei, 2016). In Table 2, the AVE scores were above 0.5 and most of the standardized loadings were $>0.7$, suggesting convergence validity (Ravand \& Baghaei, 2016). Discriminant validity (i.e. not shown in the study) was achieved by determining which loadings of each construct (i.e. job satisfaction, affective commitment, distributive justice, job-related wellbeing, and employee engagement) "were higher than loadings on other constructs" (Ravand \& Baghaei, 2016:4).

Hypotheses testing: To develop the statistical model that shows the antecedents of affective commitment of HRM practitioners (i.e. refer to Figure 1), structural equation modelling (SEM) was conducted. Before testing the hypotheses developed in the theoretical section, the authors conducted model fit indexes (refer to Table 3). The model showed an acceptable fit based on the comparative fit index (CFI) $=0.92$ (Hu \& Bentler, 1999, recommend from 0.90 to 0.95 ) and root mean square era (RMSEA) $=0.10$ (Hu \& Bentler, 1999, recommend greater than 0.05 ). The other goodness of fit indicators were poor, $\chi 2=567.06$ with 219 degrees of freedom $(\mathrm{p}<0.001)$, standard root mean square $(\mathrm{SMMR})=0.89(\mathrm{Hu} \&$ Bentler, 1999, recommend less than or equal 0.08 ). It is argued that $\chi 2$ is usually affected by the sample size (Kline, 2011).

The data from Table 3 indicate a strong significant positive relationship between distributive justice and job satisfaction $(\beta=0.61 ; p \leq 0.001)$. Therefore, Hypothesis 1 is supported. Similarly, Saadati et al. (2016) found that distributive justice positively related with job satisfaction. The data from Table 3 show that there is an insignificant low positive relationship between job-related well-being and job satisfaction $(\beta=0.05 ; \mathrm{p} \geq$ 0.001). Therefore, Hypothesis 2 is not supported. Elsewhere, it was found that as job satisfaction increased, so did job-related well-being (Faragher et al., 2005) and the result was happy employees (Bakker \& Oerlemans, 2011) who enjoyed their work (Rothausen, 2013) and who were productive (Bakker \& Oerlemans, 2011). As can be observed from Table 3 , there is an insignificant low negative relationship between employee engagement and job satisfaction $(\beta=-0.02 ; p \geq 0.001)$. Therefore, Hypothesis 3 is not supported. This finding contradicts previous research where it was found that employee engagement positively related with job satisfaction (Hanaysha, 2016). Table 4indicates that positive emotions only mediated the relationship between distributive justice and job satisfaction $(\beta=0.36$; $p \geq 0.001)$.Based on this finding, Hypothesis 4 is partially supported. A closer look at Table 3 shows that there is a strong significant positive relationship between job satisfaction and affective commitment $(\beta=0.70 ; p \leq 0.001)$. Therefore, Hypothesis 5 is supported. All the means of positive emotions were below the mid-point of 4 , suggesting that the respondents were not happy or satisfied with their wages. This finding is surprising because 183 out of 300 respondents earned R20 000.00 and above per month. It also emerged from the data that there was a strong significant 
positive relationship between job satisfaction and affective commitment $(\beta=0.70 ; p \leq 0.001)$. This finding is consistent with previous research (Bilgin \& Demirer, 2012; Kaplan et al., 2012; Lumley et al., 2011).

Table 3: Direct effects between distributive justice, job-related well-being, employee engagement, job satisfaction, and affective commitment

\begin{tabular}{|c|c|c|c|c|}
\hline Structural job satisfaction $\leftarrow$ & Coefficient & $\mathbf{P}>|\mathbf{z}|$ & $\begin{array}{l}\text { Standard } \\
\text { coefficient }\end{array}$ & error \\
\hline Positive emotions & 0.32 & $0.00^{* * *}$ & 0.67 & \\
\hline Distributive justice & 0.61 & $0.00^{* * *}$ & 0.10 & \\
\hline Job-related well-being & 0.05 & 0.53 & 0.09 & \\
\hline Employee engagement & -0.02 & 0.87 & 0.12 & \\
\hline $\begin{array}{l}\text { Structural } \\
\text { commitment } \leftarrow\end{array} \quad$ affective & Coefficient & $P>|z|$ & $\begin{array}{l}\text { Standard } \\
\text { coefficient }\end{array}$ & error \\
\hline Job satisfaction & 0.70 & $0.00^{* * *}$ & 0.10 & \\
\hline
\end{tabular}

Table 4: Positive emotions as a mediator

\begin{tabular}{llll}
\hline Structural job satisfaction $\leftarrow$ & Coefficient & $\mathbf{P}>|\mathbf{z}|$ & $\begin{array}{l}\text { Standard } \\
\text { coefficient }\end{array}$ \\
\hline Distributive justice & 0.36 & $0.00^{* * *}$ & 0.20 \\
Job-related well-being & -0.00 & 0.33 & 0.04 \\
Employee engagement & 0.06 & 0.24 & 0.05 \\
\hline
\end{tabular}

\section{Conclusion and Recommendations}

Based on the study findings, it can be concluded that HRM practitioners rated measures used in this study positively, with the exception of the positive emotions items, which were remuneration related, and as a result organizations might find it difficult to retain HRM practitioners and motivate to perform their dual role effectively. The literature and data showed that AET is an appropriate theoretical framework to determine antecedents of affective commitment. It is thus recommended that organizations should investigate the reasons why HRM practitioners rated the affective commitment items negatively and why HRM respondents would not spend the rest of their careers with their organizations. HRM practitioners implement peoplerelated policy to enhance positive employee emotions but they are employees themselves, and positive work emotions also influence their work performance. Organizational policy should therefore also focus on developing HR talent (soft skills) in the organization and not solely focus on hard-core business skills. The researchers recommend that a similar longitudinal study should be conducted, using a mixed-methods research design. Future research can also determine significant differences in terms of age, gender, and educational levels. 
Based on the study results, the SEM model as developed is shown below:

Figure 2: Antecedents of affective commitment

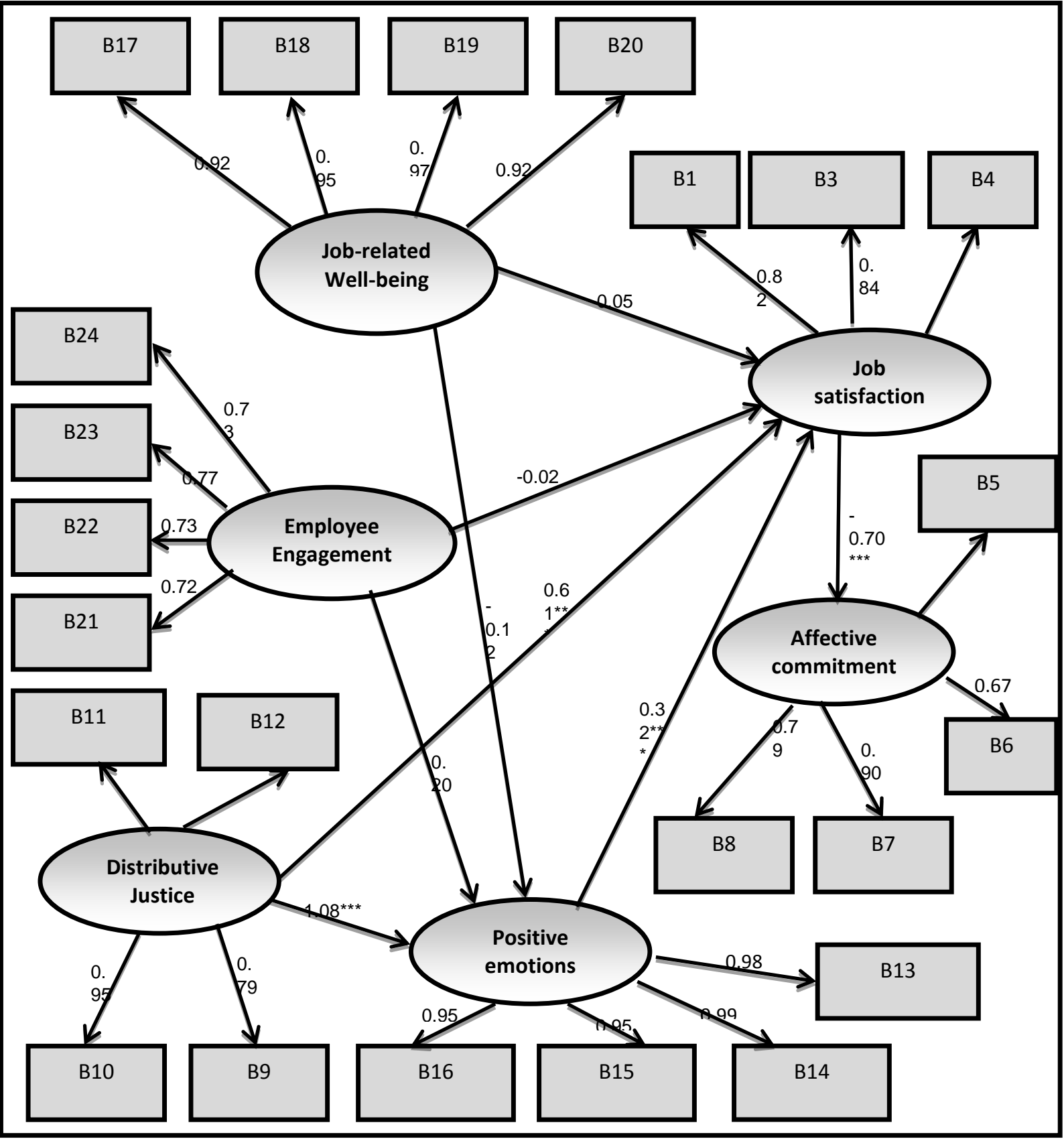

Acknowledgements: The authors of the paper wish to thank Prof. Stuart Carr, from Massey University, for helping to conceptualise the study. We are also grateful for IPM for its unwavering support. 


\section{References}

Abbott, G. N., White, F. A. \& Charles, M. A. (2005). Linking values and organizational commitment: A correlational and experimental investigation in two organizations. Journal of Occupational and Organizational Psychology, 78, 531-552.

Adams, J. S. (1965). Inequity in social exchange. In L. Berkowitz (Ed.), Advances in Experimental Social Psychology. Volume 2(pp. 267-299). New York: Academic Press.

Agarwala, T. (2003). Innovative human resource practices and organizational commitment: An empirical investigation. International Journal of Human Resource Management, 14(2), 175-197.

Akram, U., Khan, M. K., Yixin, Q., Bhatti, M. H., Bilal, M., Hashim, M. \& Akram, Z. (2016). Impact of organizational justice and job satisfaction of banking employees. European Journal of Business and Management, 8(16), 55-63.

Ali, M. \& Saifullah, Z. (2014). Distributive justice and procedural justice as predictors of job satisfaction and organizational commitment: A case study of Banking sector of Baluchistan. European Journal of Business and Management, 6(34), 69-75.

Allen, N. J. \& Meyer, J. P. (1990). The measurement and antecedents of affective, continuance and normative commitment to the organization. Journal of Occupational Psychology, 63(1), 1-18.

Altahayneh, Z. L., Khasawneh, A. \& Abedalhafiz, A. (2014). Relationship between organizational justice and job satisfaction as perceived by Jordanian physical education teachers. Asian Social Science, 10(4), 131138.

Amos, P. M., Acquah, S., Antwi, T. \& Azifome, N. S. (2015). A comparative study of factors influencing male and female lecturers' job satisfaction in Ghanaian higher education. Journal of Education and Practice, 6(4), 1-11.

Andolsek, D. M. \& Stebe, J. (2004). Multinational perspectives on work values and commitment. International Journal of Cross Cultural Management, 4(2), 181-209.

Azeem, S. M. (2010). Job satisfaction and organizational commitment among employees in the Sultanate of Oman. Psychology, 1(4), 295-299.

Bakker, A. B. \& Oerlemans, W. (2011). Subjective Well-being in Organizations. In K.S. Cameron \& G.M. Spreitzer (Eds.), The Oxford Handbook of Positive Organizational Scholarship (pp. 178-189). New York: Oxford University Press.

Bilgin, N. \& Demirer, H. (2012). The examination of the relationship among organizational support, affective commitment and job satisfaction of hotel employees. Procedia Social and Behavioural Sciences, 51, 470-473.

Biswas, S. \& Bhatnagar, J. (2013). Mediator analysis of employee engagement: Role of perceived organizational support, person-organization fit, organizational commitment and job satisfaction. Vikalpa, 38(1), 27-40.

Cabrera, E. F. (2017). The six essentials of workplace productivity. People and Strategy, 35(1), 50-60.

Chatzoglou, P. D., Vramaki, E., Komsiou, E., Polchrou, E. \& Diamantidis, A. D. (2011). Factors affecting accountants' job satisfaction and turnover intentions: A structural equation model. $8^{\text {th }}$ International Conference on Enterprise System, Accounting and Logistics (pp. 130-147).

Chew, J. \& Chan, C. C. A. (2008). Human resources practices, organizational commitment and intention to stay. International Journal of Manpower, 29(6), 503-522.

Christensen, L. B., Johnson, R. B. \& Turner, L. A. (2015). Research Methods, Design, and Analysis. Boston: Pearson Education Limited.

Deepa, E. \& Kuppusamy, S. (2014). Impact of performance appraisal system on job satisfaction, employee engagement, organizational citizenship behaviour and productivity. Indian Journal of Applied Research, 4(2), 4-6.

Diener, E., Sandvik, E. \& Pavot, W. (1991). Happiness is the Frequency, not the Intensity of Positive versus Negative Affect. In F. Strack, M. Argyle\& N. Schwarz (Eds.), Subjective Well-being: An Interdisciplinary Perspective (pp. 119-139). New York: Pergamon.

Eslami, J. \& Gharakhari, D. (2012). Organizational commitment and job satisfaction. Journal of Science and Technology, 2(2), 85-91.

Fachrunnisa, 0. \& Mutamimah, A.A. (2014). The role of work place spirituality and employee engagement to enhance job satisfaction and performance. The International Journal of Organizational Innovation, $7(1), 15-35$. 
Faragher, E. B., Cass, M. \& Cooper, C. L. (2005). The relationship between job satisfaction and health: Ametaanalysis. Occupational and Environmental Medicine, 62(2), 105-112.

Fareed, M., Isa, M. F. M. \& Noor, W. S. W. M. (2016). HR professionals' effectiveness through human capital development, organizational culture and high performance work system: A proposed framework. International Business Management, 10(9), 1720-1728.

Fatt, C. K., Khin, E. W. \& Heng, T. N. (2010). The impact of organizational justice on employee's job satisfaction: The Malaysian companies perspective. American Journal of Economics and Business Administration, 2(1), 56-63.

Field, A. (2013). Discovering Statistics Using IBM SPSS Statistics. London: Sage Publications.

Frederickson, B.L. (2004). The broaden-and-build theory of positive emotions. Philosophical B: Biological Sciences, 359, 1367-1377.

Fu, F. Q., Bolander, W. \& Jones, E. (2009). Managing the driver of organizational commitment and salesperson effort: An application of Meyer and Allen's three-component model. Journal of Marketing Theory and Practice, 17(4), 335-350.

Giffords, E. D. (2009). An examination of organizational commitment and professional commitment and the relationship to work environment, demographic and organizational factors. Journal of Social Work, 9(4), 386-404.

Gubbins, C. \& Garavan, T. (2016). Social capital effects on the career and development outcomes of HR professionals. Human Resources Management, 55(2), 241-260.

Hanaysha, J. (2016). Determinants of job satisfaction in the higher education sector: Empirical insights from Malaysia. International Journal of Human Resource Studies, 6(1), 129-146.

Hao, Y., Hao, J. \& Wang, X. (2016). The relationship of organizational justice and job satisfaction: Evidence from China. Journal of Chinese Human Resource Management, 7(2), 115-128.

Heidari, S. A. \& Saeedi, N. (2012). Studying the role of organizational justice on job satisfaction (Case study: An Iranian Company). Journal of Basic Applied Science of Research, 2(7), 6459-6465.

Hochwarter, W. A. \& Thomson, K. R. (2010). The mediating role of optimism on politics-outcomes relationships: A test of competing perspectives. Human Relations, 63(9), 1371-1394.

Hu, L. \& Bentler, P. M. (1999). Cut-off criteria for fit indexes in covariance structure analysis: Conventional criteria versus new alternatives. A Multidisciplinary Journal, 6(1), 1-55.

Imam, A. \& Shafique, M. (2014). Impact of employee engagement in retaining employees through mediating effect of job satisfaction and organizational commitment and moderating effect of job stress: A corporate banking sector study in Pakistan. Journal Applied of Environment and Biological Sciences, $4(12), 1-5$.

Kamalanabhan, T. J., Prakash Sai, L. \& Mayuri, D. (2009). Employee engagement and job satisfaction in the information technology industry. Psychological Reports, 105(3), 759-770.

Kanchana, P. \& Panchanatham, N. (2015). Impact of affective commitment on job satisfaction. International Journal of Management and Social Science, 4, 302-316.

Kaplan, M., Ogut, E., Kaplan, A. \& Aksay, K. (2012). The relationship between job satisfaction and organizational commitment: The case of hospital employees. World Journal of Management, 4, 22-29.

Karim, N. H. A. (2008). Relationship between job satisfaction and affective commitment: Investigating the correlates and predictors' of job satisfaction among Malaysian academic librarians. Malaysian Journal of Library and Information Science, 13(2), 69-88.

Keramati, M. R., Eslamieh, F. \& Mozaiini, M. (2015). A study on the relationship between organizational justice and job satisfaction (Case study of social security organization, Markazi, Iran). Indian Journal of Fundamental and Applied Life Sciences, 5(S4), 961-968.

Kirsten, T. J., Van der Walt, H. L. \& Viljoen, J. T. (2009). Health, well-being and wellness: An anthropological eco-systematic approach. Journal of Interdisciplinary Health Science, 14(1), 1-7.

Kline, R. B. (2011). Principles and Practice of Structural Equation Model (2nd ed.).New York, NY: The Guildford Press.

Kumar, R. \& Eng, K. G. (2011). Perceived organizational commitment and its impact to the turnover intention: A correlation analysis. Journal of Global Business and Economics, 4, 40-57.

Liou, K. T. (1995). Professional orientation and organizational commitment among public employees: An empirical study of detention workers. Journal of Public Administration Research and Theory, 5(2), 231-247. 
Locke, E. A. (1976). The Nature and Causes of Job Satisfaction. In M.D. Dunnette (Ed.), Handbook of Industrial and Organizational Psychology (pp. 1297-1349). Chicago, IL: Rand McNally.

Lumley, E. J., Coetzee, M., Tladinyane, R. \& Ferreira, N. (2011). Exploring the job satisfaction and organizational commitment of employees in the information technology environment. Southern African Business Review, 15(1), 100-118.

Lyubomirsky, S., King, L. \& Diener, E. (2005). The benefits of frequent positive affect: Does happiness lead to success? Psychological Bulletin, 131(6), 803-855.

Macey, W. H. \& Schneider, B. (2008). The meaning of employee engagement. Industrial and Organizational Psychology, 1, 3-30.

Maleka, M. J. (2017). Exploring the relationship between a living wage and human resources outcomes: Evidence from Tshwane Marabastat Mall. In press.

Maleka, M. J., Skosana, T. B. \& Lekgothoane, P. (2016). Work satisfaction of municipality employees while performing duties under the conditions of limited resources. Public and Municipal Finance, 5(3), 3946.

Masindi, T. (2015). The influence of job satisfaction and organizational commitment on turnover intention (Thesis). Cape Peninsula University of Technology, Cape Town.

Meyer, J. P. \& Allen, N. J. (1997). Commitment in the Workplace: Theory, Research and Application. Newbury Park, CA: Sage Publications.

Meyer, J. P. \& Herscovitch, L. (2001). Commitment in the workplace: Towards a general model. Human Resources Review, 11, 299-326.

Miao, R. (2011). Perceived organizational support, job satisfaction, task performance and organizational citizenship behaviour in China (Thesis). University of Science and Technology Liaoning Anshan, China.

Mohapatra, M. \& Sharma, B. R. (2008). Drivers of organizational commitment among managers of industrial organizations: A case study. Global Business Review, 9(1), 51-63.

Nohria, N., Groysberg, B. \& Lee, L. E. (2008). Employee motivation: A powerful new model. Harvard Business Review, 86(7-8), 78-82.

O'Reilly, C. A. \& Chatman, J. A. (1986). Organizational commitment and psychological attachment - The effects of compliance, identification and internalization of pro-social behaviour. Journal of Applied Psychology, 71(3), 492-499.

Ouweneel, E., Le Blanc, P. M. \& Schaufeli, W. B. (2011). Flourishing students: A longitudinal study on positive emotions, personal resources, and study engagement. The Journal of Positive Psychology, 6(2), 142153.

Pereira, V. S. \& Fontinha, R. (2016). An exploration of the role duality experienced by HR professionals as both implementers and recipients of HR practices: Evidence from Indian Railways. Human Resource Management, 55(1), 127-142.

Price, L. L. \& Mueller, C. W. (1986). Handbook of Organizational Measurement. Marshfield, MA: Pitman.

Rahman, M., Haque, M., Elahi, R. \& Miah, W. (2015). Impact of organizational justice on employee job satisfaction: An empirical investigation. American Journal of Business \& Management, 4(14), 162-171.

Ravand, H. \& Baghaei, P. (2016). Partial least square structural equation using R. Practical Assessment, Research and Evaluation, 21(11), 1-16.

Rhoades, L., Eisenberger, R. \& Armeli, S. (2001). Affective commitment to the organization: The contribution of perceived organizational support. Journal of Applied Psychology, 85(5), 823-836.

Robbins, S. T. J. \& Judge, T. A. (2015). Organizational behavior (16th ed), Boston: Pearson Education Limited.

Rothausen, T. J. (2013). Hedonic and Eudaimonic job-related well-being: Enjoyment of job and fulfilment of job purpose. $\quad$ Retrieved on 03 April 2017 from http://ir.stthomas.edu/cgi/viewcontent.cgi?article=1000\&context=ocbmgmtwp.

Saadati, M., Saadati, A., Asghari, A., Bidgoli, M. G., Ghodsi, A. \& Bidgoli, A. G. (2016). The relationship between perceived organizational justice, organizational commitment and job satisfaction. Health, Spirituality and Medical Ethics, 3(1), 10-17.

Saliu, A. Y., Gbadeyan, R. A. \& Olujide, J. O. (2015). Organizational commitment and job satisfaction of security operatives in selected tertiary institutions in Kwara State. Asia Pacific Journal of Multidisciplinary Research, 3(4), 43-49.

Schaufeli, W. B. \& Bakker, A. B. (2003). Utrecht work engagement scale: Preliminary manual. Utrecht: Occupational Health Psychology Unit, Utrecht University. 
Schiopu, A. F. (2015). Workplace emotions and job satisfaction. International Journal of Economic Practices \& Theories, 5(3), 277-282.

Sharma, B. R., Mohapatra, M. \& Rai, S. (2013). Organizational commitment as a measure of managerial motivation: Search for its predictors in a multinational organization. Management and Labour Studies, 38(3), 139-153.

Shuck, B. \& Reio, G. (2013). Employee engagement and well-being: A moderation model and implications for practice. Journal of Leadership \&Organizational Studies, 21(1), 43-58.

Spector, P. (1985). Measurement of human service staff satisfaction: Development of job satisfaction survey. American Journal of Community Psychology, 13(6), 693-713.

Stallworth, H. L. (2003). Mentoring, organizational commitment and intention to leave public accounting. Managerial Auditing Journal, 18, 405-418.

Sunny, R. T. \& Joshua, A. J. (2014). Employee engagement: An imperative for creating job satisfaction in evolving workplace. International Conference on Emerging Trends in Engineering \& Management (pp. 18-21).

Tat, H. H., Pei-Nid, T. \& Rasli, A. M. (2012). Job satisfaction and organizational commitment in a Malaysian public university library. International Journal of Management Science \&Business Research, 1, 1-7.

Tladinyane, R. \&Van der Merwe, M. (2016). Career adaptability and employee engagement of adults employed in an insurance company: An exploratory study. South African Journal of Human Resources Management, 14(1), 1-9.

Tufail, M. S., Muneer, S. \& Ishtiaq, M. (2016). Job Characteristics with Task and Contextual Performance: Moderating Role of Procedural Justice for Front Line Managers. Abasyn Journal of Social Sciences, Special Issue.

Watson, D., Clark, L. A. \& Tellegen, A. (1998). Development and validation of brief measures of positive and negative affect: The PANAS scales. Journal of Personality \& Social Psychology, 54(6), 1063-1070.

Wegge, J., Van Dick, R., Fisher, G. K., West, M. A. \& Dawson, J. F. (2006). A test of basic assumptions of affective events theory (AET) in call centre work. British Journal of Management, 17(3), 237-254.

Weiss, H. M. \& Cropanzano, R. (1996). Affective event theory: A theoretical discussion of the structure, causes and consequences of affective experience at work. Research in Organizational Behavior, 18, 1-74.

Yucel, I. (2012). Examining the relationship among job satisfaction, organizational commitment and turnover intention. International Journal of Business \& Management, 7(20), 44-58. 